ISBN 978-93-84468-92-7

International Conference on Issues in Education, Literature, Humanities and Social Sciences

(IELHSS-2017)

Kuala Lumpur (Malaysia) Jan. 4-5, 2017

\title{
Preserving Peace and Humanity through Walt and Keki's Poem
}

\author{
Rajani Tewari \\ Assistant Professor, SOS.J.N. Kaul Institute of Education, Bhimtal, Dist.-Nainital, India
}

\begin{abstract}
Peace is very important in this world as no one can survive in this world without it. It is the need of the hour. In todays world we can see that everyone is running after materialistic things which would never make anyone happy and if someone has something their need only increases. Happiness is a state of mind and that would come only when one realizes inner peace. Humanity is also important as everyone on this earth has the right to live with dignity, respect and get equal opportunity to education and job. They should have freedom of speech, freedom of movement, freedom of religion. There should be no exploitation or gender biasedness. There should be no discrimination on the basis of caste, creed or religion. There should be no differenced on the basis of economic status. Peace can be preserved by educating human beings especially the children. They should be taught poems of Walt and Keki which would help in bringing revolution in this world. It would help in learning about human feelings, emotions being emphathetic, kind, loving etc which would definitely help in transforming the world and make it better place to live in.
\end{abstract}

Keywords: Compassion, Holistic, Responsibility, Fraternity, Comradeship

\section{Introduction}

As since past many ages man has fought for his freedom so why not preserve it now and stop all wars and become human beings. We can develop moral values, aesthetic sense, feelings like love, kindness, care ,compassion which is why we are different from animals so why not develop those qualities and elevate our higher self which is the dire need of the hour. Lets stop any kind of violence, riots, fights on petty things and become responsible towards the society. Lets broaden our mental horizon that who we are, why we are on this earth?

\section{Duty Towards Society Aim-Preserving Peace}

Why there is greed for power, domination, lust etc .Man seems like running his whole life after something and than at last gets tired and dies. Why can't we think that we all are one? This whole world is made by same God .For this we have to make our children realize the importance of human values. We all have duty, responsibility towards society. We have to give to the society what we have take from it .We have to help the needy and the downtrodden. We should not fight only for our own rights but every ones rights. We should respect others, ideas, thoughts, religion etc.

\section{Ethics and Moral Values}

Students should be taught about ethics, culture, tradition about moral values, they should also be taught about spirituality, yoga, meditation, justice, to respect everyone and treat everyone with dignity starting from home itself. They should be asked to spend time in the old age home with old age people and they should be asked to serve them, they should be asked to play with the orphans in the orphanage, prepare something like toys, cards, candles 
for them and gift it to them so that they feel a sense of responsibility towards the society. They should be asked to help the blind people while crossing the road. They should be asked to share what they have like lunch with friends. They should also be taken for field excursion and asked to clean up the ground, park etc, volunteer for blood donation, help in taking the injured and wounded to the hospital etc.

\section{Keki and Walt Whitman Poems-For Students}

They should be taught poems which should be included in their syllabus ideal poems of like of Keki and Walt Whitman. As students are the future of country and the development of the country depends upon their hands. They are the one who can help in making this world a better place to live in. They can really transform this world if they are determined. Students should be molded in such a manner that this world becomes a heaven. They should be told the fruit of labor is always sweet and the benefits of it.

\section{Teaching About Ideal People}

They should be told about how our ancestors have fought for peace and freedom and now it is their responsibilities to preserve peace and humanity for that they have to be taught about great leaders, kings great ideals like-Mahatma Gandhi, Abraham Lincoln ,King Asoka who fought for and sacrificed for the people. As we had many great people like Swami Vivekananda and Rabindranath Tagore, etc who talked about peace, love, brotherhood they gave this message to the whole world therefore students should be taught about them. Through audio-visual aids, role playing, projectors, excursion, tours they should be taught about the history as well as the present society as they would be able to see the changes and learn more about culture and traditions as well as society.

\section{Keki. N. Daruwalla and Walt Whitman's Aim-Humanity}

For that we have to take some serious steps like to teach the students in the class poems of Walt Whitman and Keki. N .Daruwalla . Walt poems teaches about Universal Brotherhood, democratic world, love kindness, care, compassion, justice, fraternity, comradeship etc.

Keki .N.Daruwalla teaches about struggles, hardships and difficulties faced by the common masses .He talks about death, diseases, riots ,war, partition of India and Pakistan and what consequences people had to face due to it.

These both the poets talks about corruption, injustice, exploitation, human trafficking and vices existing in the society. Keki says that the greed for power, lust, domination of one race by the other that has always existed and would always remain so that is human nature.

\section{Walt's Message -}

Whereas Walt wants to transform this world by spreading the message that we all are a part of the same God. When we all would die we all will stay in this Universe and be born again like a leaf of grass. Our only body dies he says but the soul always remain alive we are only changing bodies when we die like we change clothes. We all become one when we die. Than there is no difference between rich or poor .He was against any kind of war. He wanted that everyone should get justice especially the blacks, he wrote for Abraham Lincoln that how he sacrificed his life for the people. How he fought for people's rights and saved America from the outside dangers .How he made America win by laying down his life for it. He feels that animals are more happy than us. They are not competitive or complaining like us. They love each other. They sleep peacefully they have a relaxed life.

They have no worries. They take care of each other poet feels that they have learnt it from him. He feels that why human beings can't learn it from them. 


\section{Keki's Message -}

Keki also tells about fake rituals which takes place in ghats, the bodies on the river floats half burnt .How the death is caused due to diseases. How man is struggling for survival staying in places where there are only mosquitoes who are ready to bite you and that place is without any electricity or fan and it's pathetic hot still man struggles for earning. How riots takes place within a second and how innocent people die for no reason. How Asoka feels sad after Kalinga war as millions of people are dead and there is a river of blood flowing between him and the common masses and therefore he can't come closer to them .He says to his messenger that please dig my message so deeply, engrave it on the rocks (stupa) so deeply which would leave a message even for the coming generations to come that how deeply he was hurt by the consequences of kalinga war and that he was ready to take any abuse or curse by the people because he wanted to come closer to common masses now. As he never knew how Kalinga war would create havoc in peoples life .As he could only see widows wailing, orphans crying, there was a pool of blood flowing everywhere and dead bodies cut into pieces lying here and there scene which was horrific. He gave up the war and later on lead a holistic life. He wanted to serve humanity and therefore he send his messengers around the world to spread the message of peace, love and humanity. We can say that man can bring a revolution if he is determined. There is good and evil both inside human beings it's what he chooses and definitely an individual can make a difference.

\section{Their Experiences-Harsh Realities of Life}

Therefore these poems should be taught to the students which help in the broadening of their mental horizons. They can learn more about humanity, society, consequences of wars, what we can learn from others experiences that war is never a solution and the history is the proof of it that it has never gained anything from wars except death of innocent people in which women and children are mainly the victims and why to repeat others mistakes. We should learn from past mistakes and though not repeat the same.

\section{Humanity and Peace in Present Scenario}

Preserving humanity and peace is very important in the present scenario as we can see due to increase in arms and weapons and children especially they are playing video games which shows violence ,on television they are exposed to all sorts of violence and not the internet and mobiles there is no way they can escape for that a strict vigilance should be done by the parents ,teachers, siblings and the society members. They should keep a watch on what they are watching, playing etc. They should shoulder the responsibility by setting good examples and being an ideal for them .Home is the first school for children therefore it must be seen that they learn love ,kindness, care, compassion, peace at home .Parents or siblings should not fight. Even the society is responsible if the child becomes violent because he is learning by observing and as they are a copy cat as they are keen observer and curious to learn everything. Therefore even society should maintain peace, live in harmony, care for their neighbours etc and stop any kind of violence against women .children, old people or downtrodden etc and thus help in making a peaceful and loving society. Parents should avoid keeping weapons at home if essential it should be beyond reach of the children.

\section{Suggestions-Poem Reading and Writing-Leading to Better Future Citizens}

Poem reading and writing is a part of becoming creative. Children should be made innovative and creative as they would be able to express their imagination, feelings, emotions, ideas, thoughts through poem writing and would be able to express their suppressed feelings in a better manner. They would learn to be emphatic and would be able to develop their aesthetic sense. As their problems and conflicts can also be resolved by poem writing and reading they would therefore be able to attain inner peace. If one is at peace with oneself than only they can be at peace with others and they can make others happy who surrounds them and the people would like their company as 
they are always joyful and they don't have the feelings like of hatred, enmity, jealousness etc. Thus for this they should be taught poems like of Keki and Walt who were great poets as when their poems would be read people would learn more about human feelings, their emotions, thoughts ,conspiracies, difficulties and struggles ,learn about different cultures and thus their imaginative power would also develop to a very great extent .They would thus imbibe what is good for all, goodness and welfare for all.

\section{Conclusion}

Students would come to know about the truth which is beauty and beauty which is the God Satyam, Shivam , Sundram etc and thus help in preserving humanity ,peace, love, culture and tradition. As they are the future citizens and development of the country as well as the world depends upon them. They would be able to become better human beings morally and ethically developed through the poems taught by Keki and Walt Whitman which who would help in the development of their spirits and elevating their souls. They would become more human and treat everyone with equality and thus help in preserving peace and humanity. In this manner they would help in the development of the society country as well as the whole world.

\section{References}

[1] http://www.human rights .com/sites/default/files/done.jpg

[2] Human Rights (Stanford Encyclopedia of Philosophy)

[3] http://www.new world encyclopedia.org /entry /Info: Main Page

[4] http://www.aishdas.org/gallery/community.jpg

[5] "A long story".The Indian Express. 12 May 2009.

[6] "Anthology of Contemporary Indian Poetry". BigBridge.Org. Retrieved 9 June 2016.

[7] Justin Kaplin, Walt Whitman: A Life, Harper Perennial Modern Classics,2003 p287

[8] Jump up Shively, Charley (ed): Calumus Lovers: Walt Whitman's Working Class Cammerados, Gay Sunshine Press 1987 